\title{
O DIREITO DE PROTECAO À SAÚDE MENTAL DO TRABALHADOR EM FACE DAS ORGANIZACOES DE TRABALHO CONTEMPORÂNEAS: ANÁLISE DA EFETIVIDADE JURÍDICO-FUNDAMENTAL SOBRE A OMISSÃO REGULAMENTADORA
}

\section{THE PROTECTION RIGHT TO MENTAL HEALTH OF THE WORKER IN FACE OF THE WORK ORGANIZATIONS CONTEMPORARY: ANALYSIS OF THE LEGAL EFFECTIVENESS OF THE FUNDAMENTAL RIGHT ABOUT THE OMISSION REGULATORY}

\section{RESUMO}

${ }^{1}$ Leandro Cioffi

Estudo tendo como tema o direito de proteção à saúde mental do trabalhador, com categoria de pesquisa bibliográfica, tendo por objetivo a verificação da possível efetividade desse direito nos ambientes e organizações de trabalho contemporâneos, a partir da compreensão dos modos de produção e formas de execução do trabalho, dos riscos psicossociais e algumas doenças ocupacionais consequentes, da identificação de desatualização das vigentes normas de proteção à saúde do trabalhador que implicam em prejuízos na efetiva proteção à saúde mental do mesmo, e da compreensão de tal direito na perspectiva dos direitos fundamentais e questões hermenêuticas envolvidas para a sua concretização, tendo como método de abordagem dialético, conflitando o elemento concreto assentado na estruturação do ambiente e organização de trabalho e suas consequências lesivas à saúde mental do trabalhador, com o elemento abstrato assentado nas vigentes normas de proteção à saúde do trabalhador, de direitos fundamentais relacionados e questões hermenêuticas envolvidas, e tendo como procedimento técnico o estudo bibliográfico envolvendo livros, artigos publicados em periódicos, manuais e acrescentando a utilização de documentos jurídicos.

Palavras-chave: Saúde mental do trabalhador, Doenças relacionadas ao trabalho, Efetividade de direitos

\begin{abstract}
Study on the theme of the protection right to mental health of the worker, with category of bibliographic research, with the objective of verifying the possible effectiveness of this right in the environments and contemporary work organizations, from the understanding of the modes of production and forms of execution of work, psychosocial risks and some consequential occupational diseases, the identification of outdating of the protection right to mental health of the workers that imply losses in the effective protection of mental health of such persons, and understanding of this right in the perspective of the fundamental rights and hermeneutical issues involved for their achievement, having the dialectic as method of approach, putting in conflict the concrete element seated in structuring the environment and working organization and its detrimental consequences to mental health worker, with the abstract element seated in the current norms of protection to mental health of the worker, related fundamental rights and involved hermeneutical questions, as a technical procedure, the bibliographic study of books, articles published in journals, handbooks, adding the use of legal documents.
\end{abstract}

Keywords: Mental health of the worker, Diseases related to work, Effectiveness of rights

\footnotetext{
${ }^{1}$ Mestre em Direito pela Universidade Estadual Paulista Júlio de Mesquita Filho - UNESP, São Paulo (Brasil). Professor da Universidade Federal de Mato Grosso - UFMT, Mato Grosso (Brasil). E-mail: leandro.cioffi@adv.oabsp.org.br
} 


\section{INTRODUÇÃO}

O presente trabalho tem como tema o estudo do direito de proteção à saúde mental do trabalhador, delimitando-o acerca de sua efetividade nos ambientes laborais contemporâneos, ora decorrentes de organizações de trabalho instituídas com base na inserção do toyotismo como modo de produção nas relações contemporâneas, sobre as quais evidenciam a constatação de riscos psicossociais no trabalho. $\mathrm{O}$ presente estudo concentra-se na área de conhecimento do Direito do Trabalho, mas com abordagens de direitos fundamentais concernentes ao tema proposto, bem como de substratos pertencentes a áreas de conhecimento que dedicam ao estudo da saúde mental do trabalhador.

Quanto ao problema de pesquisa, sua justificativa funda-se a partir de estudos relacionados à saúde mental do trabalhador que apontam para o sentido de constatação de que, no ambiente laboral contemporâneo, o trabalho vem sendo exigido, em sua execução, sob uma maneira de organização capaz de abrigar riscos à saúde mental do trabalhador, o que vem sendo chamados de riscos psicossociais, com potencialidades de gerar graves doenças, sobretudo mentais, relacionadas ao trabalho. Porém, ao se deparar com a legislação que dispõe e regulamenta a segurança e medicina do trabalho, verifica-se uma imensa falta de regulamentação atualizada e adequada para efetivamente proteger a saúde do trabalhador exposto aos riscos supracitados. Apesar de tal omissão normativa, a saúde do trabalhador está presente no conjunto de direitos fundamentais encartados na Constituição de 1988, embora dotada de certa complexidade envolvendo a sua eficácia. Diante de tais justificativas, tem-se como problema de pesquisa proposto no presente estudo sintetizado através da seguinte indagação: a partir dos direitos fundamentais que ilustram o direito a proteção à saúde do trabalhador, inclusive mental, é possível dar efetividade a esse direito em face das organizações de trabalho dotadas de riscos psicossociais, mesmo que estes ainda não estejam regulamentados especificamente no Direito do Trabalho?

Como justificativa da presente pesquisa, com base nas razões práticas e teóricas que consubstanciam o problema de pesquisa acima, tem-se como importância para o estudo do Direito do Trabalho a busca pela compreensão mais consistente acerca dos esforços de efetividade de direitos de proteção à saúde do trabalhador em conformidade aos mandamentos de direitos fundamentais encargados na Constituição de 1988, e como relevância social justifica-se a presente pesquisa na necessidade de se ter esforços acadêmicos em busca de uma solução jurídica 
a um grande problema de pesquisa descrito acima, que afeta trabalhadores de diversos setores da atividade econômica.

Tem-se como objetivo da pesquisa verificar essa possível efetividade de direito, tendo como objetivos específicos o de compreender os modos de produção e suas respectivas formas de execução do trabalho; compreender os riscos psicossociais e algumas consequentes doenças relacionadas ao trabalho; identificar a desatualização das vigentes normas de proteção à saúde do trabalhador ora previstas no direito trabalhista que implicam em prejuízos à sua efetiva proteção em face das organizações de trabalho contemporâneas; e compreender o direito de proteção à saúde do trabalhador na perspectiva dos direitos fundamentais e suas questões hermenêuticas envolvidas no tocante a sua concretização.

O presente estudo tem como método de abordagem o dialético (MARCONI; LAKATOS, 2003, p. 106), tendo a confrontação do elemento fático (concreto) - ambiente e organização de trabalho contemporâneos, consequências lesivas à saúde mental do trabalhador e abordagens sobre doenças ocupacionais envolvidas -, com as normas (abstrato) regulamentações de proteção à saúde do trabalhador, direitos fundamentais relacionados e questões hermenêuticas envolvidas. Tem como procedimento técnico empregado a pesquisa bibliográfica (GIL, 2002, p. 45), envolvendo livros acadêmicos, artigos publicados em periódicos, manuais e acrescentando na investigação a análise de legislação e jurisprudência.

\section{DO TRABALHO E DOS MODOS DE PRODUÇÃO}

\subsection{O trabalho e o ser humano}

Para se entender o ser humano, é fundamental compreender o trabalho como um de seus elementos para distingui-lo dos demais animais. Os animais, dentre os que se encontram em mais altos níveis da escala zoológica, como por exemplo os mamíferos, não agem exclusivamente guiados pela ação instintiva e sim por ações também dotadas de inteligência, isto é, sendo capaz de responder a um problema ou situação com ações nem sempre guiadas por uma programação biológica e sim por uma resposta "improvisada, pessoal e criativa" tal como, numa jaula, um macaco faminto subindo numa caixa (improviso, criação, ação pessoal ao invés de programação biológica) para alcançar e pegar uma banana pendurada, contudo, tratando-se de uma “inteligência concreta”, a saber, uma inteligência que “[...] depende da experiência vivida "aqui 
e agora" [...] não inventa o instrumento, não o aperfeiçoa nem o conserva para o uso posterior" (ARANHA; MARTINS, 1993, p. 3-4).

Já a atividade humana, diferindo-a dos demais animais, caracteriza-se pelo "trabalho" e pela "linguagem". Sobre a linguagem, os animais até possuem-na, mas por vezes programada biologicamente (como por exemplo, o movimento das abelhas em comunicação umas as outras) ou esgotada tão somente na experiência vivida (por exemplo, algumas reações de cachorros a comandos a ele dirigidos pelo seu dono), ou seja, a linguagem do animal conhece apenas o índice (comandos que indicam algo específico, tal como aqueles utilizados num adestramento) e não o símbolo, que "[...] intervém de forma abstrata que distancia o homem da experiência vivida, tornando-o capaz de reorganizá-la numa outra totalidade e lhe dar novo sentido" e assim, dotado de inteligência abstrata. (ARANHA; MARTINS, 1993, p. 4-5).

Com relação ao trabalho, se o mesmo "[...] é a ação transformadora da realidade, na verdade o animal não trabalha, mesmo quando cria resultados materiais com essa atividade, pois sua ação não é deliberada, intencional”, de modo que o trabalho humano “[...] é a ação dirigida por finalidades conscientes [...], a resposta aos desafios da natureza na luta pela sobrevivência", e além de transformar a natureza, o trabalho também altera o ser humano no desenvolvimento de suas faculdades, ou seja, o ser humano se autoproduz pelo trabalho, tratando-se também de uma "[...] é a atividade humana por excelência, pela qual o homem intervém na natureza e em si mesmo. O trabalho é condição de transcendência e, portanto, é expressão de liberdade". (ARANHA; MARTINS, 1993, p. 5-6).

Lafer (1988, p. 213), pelo diálogo construído com o pensamento de Hannah Arendt através de sua obra "[a] reconstrução dos direitos humanos", das dimensões temporais da "vita activa" ("labor", "trabalho" e "ação"), comenta que é através do "trabalho" (diferente de uma atividade de subsistência biológica do animal laborans na definição do "labor") que "[...] o homo faber cria coisas extraídas da natureza, que assim se convertem em objetos de uso", tratando-se, portanto, de uma atividade criativa do mundo, isto é, "“[...] a objetividade do mundo feito pelo homem". Porém, apesar te tal compreensão, o referido autor narra também sobre a ênfase de Arendt no sentido da afirmação da vida da espécie ("animal laborans") de tal maneira que, “[...] praticamente, excluiu da vita activa o homo faber e a ação.” (LAFER, 1988, p. 226).

De qualquer modo, pode-se afirmar que a ação humana é coletiva e com isso a execução do trabalho é compreendida como uma "tarefa social", ou seja, o homem é um ser social, mas 
ao mesmo tempo também cada ser humano é dotado de uma individualidade (pessoa) que o distingue dos demais (ARANHA; MARTINS, 1993, p. 6-7).

A esse respeito, ressalta-se o entendimento de Duguit (2006, p. 22-23) no sentido de que, na humanidade, os seres humanos, principalmente em seus respectivos grupos, encontramse sob laços de interdependência, compreendidos como "solidariedade", sobre a qual podem se vincular como "por semelhança" (necessidades comuns satisfeitas comumente) ou "por divisão de trabalho" (anseios e aptidões distintos satisfeitos pela troca de serviços recíprocos).

Entretanto, historicamente a partir da modernidade, sobretudo com o surgimento das fábricas, coincidentes às passagens do feudalismo para o capitalismo, a acumulação de capital resultou na migração de muitos artesãos, como inevitável meio de sobrevivência, a serem obrigados a trabalhar em fábricas na forma de venda de sua força de trabalho, cujo pagamento remuneratório denominado de salário, surgindo, portanto uma nova classe social: a do proletariado. Contudo, o produto construído pelo trabalho nesse modo não pertencia mais ao homem que o criou (o proletário) e sim pelo empresário que comprou essa força-de-trabalho.

Segundo Castel (1998, p. 415-418), as relações de trabalho na sociedade industrial, dãose sob três formas dominantes e também se tornando formas dessas relações mantidas na sociedade global, a saber, a "condição proletária" (proletário como "[...] um elo essencial no processo de industrialização nascente, mas está condenado a trabalhar para se reproduzir”), a "condição operária" (em a composição das relações de trabalho dão-se por salários, mas acrescidos de outros direitos sociais) e a "condição salarial" (fenômeno de "salarização da sociedade", distinguindo os trabalhadores pela posição salarial ocupada, gerando concorrências entre eles por ascensão social).

Com esse modo de exploração do trabalho humano, tem-se a constatação de um fenômeno compreendido por sua alienação, ou seja, a coisa produzida pelo trabalho do proletariado deixa de lhe pertencer, tornando-a alheia ao seu criador e pertencente ao detentor do capital. E esse fenômeno de alienação no mundo do trabalho desdobrou-se, historicamente, em distintos modos de produção e assim em seus paradigmas do trabalho conforme a seguir.

\subsection{O taylorismo-fordismo e o toyotismo}

Antes do surgimento das fábricas e da instituição do sistema fabril nas atividades produtivas, no trabalho o homem podia atuar em todas as fases da produção, que se iniciava desde 
a projeção até a execução material. Contudo, com as divisões de trabalho, a atividade produtiva passou a ficar gradativamente complexa, separando a concepção da execução. Assim, “[...] um grupo de pessoas concebe, cria, inventa o que vai ser produzido, inclusive a maneira como vai ser produzido, e outro grupo é obrigado à simples execução do trabalho, sempre parcelado, pois a cada um cabe parte do processo.” (ARANHA; MARTINS, 1993, p. 13).

Essa noção de trabalho em processo parcelado é discorrida por Frederick Taylor estabelecendo uma racionalização nas atividades produtivas (o taylorismo), melhorando a produção, inclusive através métodos de gerenciamento da produção, mas é uma racionalização que, segundo Aranha e Martins (1993, p. 14), “[...] traz em si uma irracionalidade básica”, pois com tal modo de produção, “[d]esaparece a valorização do sentimento, da emoção, do desejo. As pessoas que aparecem nas fichas do setor de pessoal são vistas sem amor nem ódio, de modo impessoal".

Já no modo de produção fordista, além de manter as características essenciais do taylorismo (por isso a preferência do emprego da expressão "taylorismo-fordismo"), pode-se dizer que intensificou o caráter impessoal do trabalho, reduzindo-o predominantemente a atividade de execução gradativamente alheia a uma produção expressivamente intelectual e intensamente rotinizada, monótona, inclusive conflitante ao sentido do trabalho nas linhas mencionadas no subitem anterior.

\begin{abstract}
A história registra, no entanto, uma significativa resistência operária ao fordismo, uma vez que os trabalhadores sentiram a perda de seu savoir-faire e sentiram o peso de um trabalho puramente mecanizado, rotinizado [sic], gerando um alto índice de absenteísmo, aumento de paralisações e sabotagens. Em contraposição, houve considerável aumento de salário para amenizar temporariamente os problemas com a força de trabalho. (NAVARRO; PADILHA, 2007, p. 17).
\end{abstract}

A partir de meados da década de 1970, em decorrência da crise capitalista, iniciou-se um processo de reestruturação produtiva, o que, dentre diversos modelos apresentados, o modelo japonês foi o que "[...] conseguiu impor-se como o mais adequado àquela etapa de crise estrutural do capital." (ALVES, 2005, p. 413), ou seja, o toyotismo.

Trata-se de um modo de produção que, diante de uma dificuldade de espaços físicos para estoques no Japão, sendo este um dos primeiros problemas enfrentados pela fábrica Toyota, teve por objetivo desenvolver uma produção com baixos custos, e com uma demanda flexível de variados produtos, observando, inclusive, a ampliação de formas subjetivas de exploração do trabalho (NAVARRO; PADILHA, 2007, p. 18), e com esta forma de exploração, assim tendente a exigir “[...] novas qualificações do trabalho que articulam habilidades cognitivas e habilidades comportamentais", as quais passam ser "[...] imprescindíveis para a operação dos 
novos dispositivos organizacionais do toyotismo e da sua nova base técnica (a automação flexível).”(ALVES, 2007, p. 248).

Sobre a reestruturação produtiva do capital na década de 1990, uma das facetas envolvendo as relações de trabalho, de acordo com Antunes (2006, p 19) consiste na superexploração do trabalho "qualificado", "multifuncional” e "polivalente”, com baixos salários e flexibilização de direitos.

Referindo-se ao século XXI, o mesmo autor informa dando a entender que o toyotismo, não se desprezou no seu todo o modo de produção do taylorismo-fordismo, mas com outros modos de precarizar o trabalho, conforme suas colocações a seguir:

Se, entretanto, presenciamos no século XX a vigência da era da regulação do trabalho, em suas últimas décadas e no início do século XXI vivenciamos outras modalidades e modos de ser da precarização, próprias da fase da flexibilidade toyotista, com traços de continuidade e descontinuidade em relação à forma taylorista-fordista. (ANTUNES, 2013, p. 21) (grifo nosso).

Apesar de tal apontamento, reforça-se a ideia do avanço do modo toyotismo no que diz respeito à expropriação subjetiva do trabalhador, pois estudos demonstram um sentido de que o saber fazer do trabalhador vem sendo gradativamente suprimido a partir dos avanços da automação:

[...] a automação em curso sugere uma "desprofissionalização" [sic] na acepção de perda do controle dos trabalhadores sobre um saber construído a partir do exercício de uma atividade ou, que é também um efeito disso, a perda da identidade entre o sujeito de um determinado trabalho e os predicados que lhes são exigidos para realizá-lo. (PINTO, 2013, p. 170).

Conforme é possível observar, reforça-se o entendimento de que os modos de produção taylorismo-fordismo não foram, no todo, superados pelo toyotismo, pois eles se coexistem sob métodos de produção em que as divisões de trabalho convivem tanto os especializados semiqualificados (taylorismo-fordismo) quanto os polivalentes (toyotismo).

\footnotetext{
Ao longo de vários períodos de extremo aproveitamento e sucessivos racionamentos, uma parcela de atividades menos sofisticadas é reduzida a um conjunto de funções cuja absorção pelos efetivos polivalentes não é rentável, dado o alto valor de sua força de trabalho. Nesse caso, o taylorismo-fordismo introduz-se na gestão flexível, permitindo que essas atividades sejam assumidas por trabalhadores semiqualificados, embora especializados em sua execução. Configura-se, então, uma "fragmentação" nos quadros das empresas, na qual grupos de trabalhadores polivalentes coexistem com outros cujas funções são rotinizadas [sic]. Em ambas as situações, há uma tendência de redução dos trabalhadores ao estrito necessário, mas evidentemente as funções rotinizadas [sic] são muito mais adequadas ao uso de contratos temporários e, portanto, de terceirização. (PINTO, 2013, p. 172).
} 
Contudo, essa coexistência de trabalhadores semiqualificados e polivalentes intensifica um estado de tensão entre os mesmos, dando a entender acerca de uma promoção de concorrência intraoperária.

\begin{abstract}
Por essa combinação de estratégias tão díspares, os trabalhadores são postos em estado de tensão permanente. Tanto polivalentes quanto especializados devem satisfazer a índices de produtividade e qualidade crescentes, mas trabalham de acordo com métodos de organização diferentes e o fluxo do trabalho tem de ser balanceado pelos dois sistemas. Assim, por mais paradoxal que pareça, o taylorismo-fordismo dos especializados acaba controlando a qualidade dos polivalentes, enquanto o toyotismo destes controla o tempo de trabalho daqueles. Como isso ocorre? Pela organização em "times de trabalho", estes, sim o grande pilar do sistema toyotista. (PINTO, 2013, p. 172).
\end{abstract}

Desse estado de tensão entre os trabalhadores que vem se implementando nas contemporâneas relações de produção, sobretudo pela inserção do toyotismo, desencadeia-se uma série de aumento de doenças relacionadas ao trabalho ocasionadas a esses trabalhadores.

\begin{abstract}
A oclusão da própria produtividade, a intangibilidade de critérios de julgamento cada vez mais fluidos nas relações de trabalho, a incerteza quanto ao futuro e a insegurança quanto à imagem que se deve ter ou fazer nas empresas, num ambiente em que as premiações e o controle pelos pares agridem continuamente a autoestima, além da imprevisibilidade das qualificações e do desgaste físico e emocional imposto pelos intermináveis ciclos de expansão e retração, tornou os trabalhadores, em todos os níveis hierárquicos, enfermos crônicos da condição geral e que estão submetidos: a de acumulação de capital. E isso se exprime em seus corpos de várias maneiras, seja por doenças osteomusculares, como a lesão por esforços repetitivos (LER), seja por doenças psíquicas, seja por agressividade e confronto físico. (PINTO, 2013, p. 176).
\end{abstract}

Ao longo da história, o trabalho sofreu alterações não somente quanto ao modo de seu exercício, mas consequentemente percebem-se mudanças de sentidos, isto é, o que antes era um dos elementos conceituais que distinguiam o ser humano dos demais animais, o sentido do trabalho passou a sofrer deslocamentos a partir da estruturação da sociedade capitalista nas relações de produção, inclusive, no seu decorrer do tempo, sofrendo influências a partir dos modos de produção taylorismo-fordismo, e especialmente no toyotismo, passando a haver neste momento uma peculiar relação de tensões envolvendo não somente aspectos físicos, mas também os psíquicos do trabalhador nas atuais organizações de trabalho. Por consequência, na maneira como vem sendo desenvolvido nas organizações laborais contemporâneas, o trabalho vem dando sinais de promoções mais degradantes nos aspectos psíquicos do ser humano trabalhador.

\title{
2 DOS RISCOS PSICOSSOCIAIS E DAS DOENÇAS RELACIONADAS AO TRABALHO
}


Tomando como base os estudos discorridos por Baruki (2015, p. 33-35), em linhas gerais, riscos psicossociais no trabalho podem ser compreendidos no sentido de condições laborais existentes em seu ambiente cuja sua organização seja capaz de prejudicar a saúde mental do trabalhador, considerando a interação social entre seus fatores humanos e condições ocupacionais do mesmo.

De acordo com os estudos da referida autora, há uma emergência desses riscos psicossociais, ora relacionada às mudanças na organização do trabalho, sendo eles, tendo como base Dejours e outros estudos, as avaliações individuais de desempenho, a gestão de qualidade total, a constatação de que tais riscos deixam de ser apenas conhecidos para torná-los também riscos de fato e a constatação de serem riscos crescentes (BARUKI, 2015, p. 46-68).

Assim, fazendo destaque à constatação do risco psicossocial agora como status de "risco de fato", a referida autora discorre no sentido de que, essa mudança de status é possível em função dos novos conhecimentos científicos e pela alteração na percepção sobre os fatores de riscos ocupacionais. (BARUKI, 2015, p. 60). Já em relação à constatação dos riscos psicossociais como crescentes, discorre que assim é considerado:

[...] se o número de situações de perigo que concorrem para a formação desses riscos estiver crescendo; ou se a probabilidade da exposição às situações de perigo estiver crescendo; ou, ainda, se as consequências (efeitos) desses riscos sobre a saúde dos trabalhadores estiverem se agravando. (BARUKI, 2015, p. 66).

Baseado em Dejours, a referida autora transcreve as patologias ocupacionais mais preocupantes na atualidade pelos grupos de "patologias de sobrecarga" (tais como a síndrome de burnout, o karoshi, e as disfunções musculoesqueléticas), "patologias pós-traumáticas" (destacando-se transtorno de estresse pós-traumático), "patologias do assédio" (tais como o assédio moral) e as “depressões, tentativas de suicídio e suicídios”. (BARUKI, 2015, p. 69-96).

Sobre a síndrome de burnout, o Ministério da Saúde do Brasil a instituiu na lista de doenças relacionadas ao trabalho por meio da Portaria $\mathrm{N}^{\circ} 1.339$, de 18 de novembro de 1999 (BRASIL, 1999, on-line) como sendo uma das espécies de transtornos mentais e do comportamento relacionadas ao trabalho.

A síndrome de burnout (ou síndrome do esgotamento profissional), pode ser compreendida como "[...] um tipo de resposta prolongada a estressores emocionais e interpessoais crônicos no trabalho.” (BRASIL; OPAS, 2001, p. 191). Nesse sentido, essa doença:

[t]em sido descrita como resultante da vivência profissional em um contexto de relações sociais complexas, envolvendo a representação que a pessoa tem de si e dos 
outros. O trabalhador que antes era muito envolvido afetivamente com os seus clientes, com os seus pacientes ou com o trabalho em si, desgasta-se e, em um dado momento, desiste, perde a energia ou se "queima" completamente. O trabalhador perde o sentido de sua relação com o trabalho, desinteressa-se e qualquer esforço lhe parece inútil. (BRASIL; OPAS, 2001, p. 191).

Dentre os fatores de risco da síndrome de burnout descritos pelo Ministério da Saúde do Brasil e pela Organização Pan-Americana da Saúde no Brasil (OPAS), essa síndrome afeta profissionais no setor de serviços ou cuidadores, mas também em ambientes de trabalho que passam por mudanças organizacionais de reestruturação produtiva, especialmente àqueles sujeitos a mudanças compulsórias de sua jornada de trabalho e expressivas reduções de sua situação econômica. (BRASIL; OPAS, 2001, p. 192).

Sobre o karoshi, o seu vocábulo de origem japonesa "[...] é um termo médico-social para designar a morte por excesso de trabalho, por sobrecarga de trabalho" e, a esse respeito, "[s]ob o ponto de vista médico, a causa mortis de karoshi inclui: hemorragia subaracnoidal, hemorragia cerebral, infarto do miocárdio e insuficiência cardíaca aguda." (FRANCO, 2002, p. 150).

Contudo, de acordo com estudos de Franco (2002, p. 149) dá-se a entender que a ocorrência do karoshi não está determinada tão somente a exposição do trabalhador a longas jornadas de trabalho, e sim também a outros fatores tais como escalas irregulares de horários, inclusive com alternância de turnos, excessos de viagens e transferências sem que a sua família o acompanhe e deslocamentos para o trabalho.

Sobre as disfunções musculoesqueléticas por traumas repetitivos, elas “[...] são conhecidas pelas siglas: LTC (lesões por traumas cumulativos), LER (Lesão por esforços repetitivos) e DORT (distúrbios osteomusculares relacionados ao trabalho).” (BARUKI, 2015, p. 74).

Com base na contextualização de Baruki (2015, p. 74-77) é possível compreender que os traumas musculares ocupacionais não vêm sendo mais considerado estritamente numa visão mecanicista (biomecânica), ou seja, tais traumas decorrentes tão somente da incompatibilidade das exigências laborais às limitações físicas do trabalhador, mas também possivelmente por estresses oriundos de fatores psicossociais no trabalho.

Assim, exemplificando, pode-se entender que uma organização de trabalho em que há uma exaustiva atividade de movimentos repetitivos em que se exige um exagerado nível de atenção do trabalhador em não errar (ambiente de risco psicossocial) este poderá contrair uma disfunção musculoesquelética que tanto pode decorrer da mera atividade física quanto também pode ser uma reação a um sofrimento psíquico. 
Sobre o transtorno de estresse pós-traumático, tal patologia é assim caracterizada como sendo "[...] uma resposta tardia e/ou protraída a um evento ou situação estressante (de curta ou longa duração) de natureza excepcionalmente ameaçadora ou catastrófica. E, reconhecidamente, causaria extrema angústia em qualquer pessoa.” (BRASIL; OPAS, 2001, p. 181). Isso ocorre, por exemplo, numa situação em que o indivíduo for vítima de algum ato de sequestro ou de terrorismo.

Em relação aos fatores de risco ocupacional, o risco de um trabalhador desenvolver em si um transtorno de estresse pós-traumático relacionado ao trabalho "[...] parece estar relacionado a trabalhos perigosos que envolvem responsabilidade com vidas humanas, com risco de grandes acidentes, como o trabalho nos sistemas de transporte ferroviário, metroviário e aéreo, o trabalho dos bombeiros, etc." (BRASIL; OPAS, 2001, p. 181).

Sobre o assédio moral no trabalho, com base nas fundamentações de Baruki (2015, p. 88), o assédio moral propriamente dito por si só se configura como uma patologia, cuja sua epidemia é evidenciada pela tamanha expansão de sua pesquisa e divulgação.

\footnotetext{
Ao contrário do que acontece com as patologias de sobrecarga, ou mesmo as patologias pós-traumáticas, o assédio moral é uma "patologia", tomando o termo em seu sentido mais amplo, bastante debatida fora do âmbito acadêmico, sendo frequentemente objeto de reportagens em revistas e jornais de grande circulação. A ampla divulgação do assunto na grande mídia reflete a epidemia que se vive em relação aos casos de assédio moral no trabalho. (BARUKI, 2015, p. 88).
}

A referida autora, baseando-se em Dejours, explica no sentido de que, no assédio moral nas relações de trabalho subordinado, o que se têm de novo são as patologias e não os fenômenos em si, e que a suscetibilidade dos sujeitos decorrem de características da nova organização de trabalho que vão além da produtividade, tais como problemas pessoais entre os sujeitos envolvidos (BARUKI, 2015, p. 88).

Sobre as depressões, tentativas de suicídio e suicídios, a referida autora comenta que “[...] das entidades mórbidas aqui agrupadas, existem muitos indícios de inter-relação os quais permitem constatar uma tríade de entidades clínicas que, sob o prisma ocupacional, perfazem um verdadeiro subgrupo.” (BARUKI, 2015, p. 93).

Episódios depressivos encontram-se arroladas dentre as espécies de transtornos mentais e do comportamento relacionados ao trabalho, de acordo com a Portaria do Ministério da Saúde do Brasil No 1.339, de 18 de novembro de 1999 (BRASIL, 1999, on-line), apesar deste ato administrativo não indicar fatores de risco psicossociais como fatores de risco de 
natureza ocupacional. De qualquer modo, o Ministério da Saúde do Brasil e a Organização PanAmericana da Saúde no Brasil descrevem episódios depressivos como aqueles que se caracterizam:

$$
\begin{aligned}
& \text { [...] por humor triste, perda do interesse e prazer nas atividades cotidianas, sendo } \\
& \text { comum uma sensação de fadiga aumentada. O paciente pode se queixar de dificuldade } \\
& \text { de concentraçãa, pode apresentar baixa auto-estima [sic] e autoconfiança, desesperança, } \\
& \text { idéias [sic] de culpa e inutilidade; visões desoladas e pessimistas do futuro, idéias [sic] } \\
& \text { ou atos suicidas. O sono encontra-se freqüentemente [sic] perturbado, geralmente por } \\
& \text { insônia terminal. O paciente se queixa de diminuição do apetite, geralmente com perda } \\
& \text { de peso sensível. Sintomas de ansiedade são muito freqüentes [sic]. A angústia tende a } \\
& \text { ser tipicamente mais intensa pela manhã. As alterações da psicomotricidade podem } \\
& \text { variar da lentificação [sic] à agitação. Pode haver lentificação [sic] do pensamento. } \\
& \text { (BRASIL, OPAS, 2001, p. 178) (grifo nosso). }
\end{aligned}
$$

No tocante aos fatores de risco ocupacional conhecidos, além das demais hipóteses de exposição a determinadas substâncias químicas tóxicas, constatam-se que a relação entre episódios depressivos com o trabalho pode se dar também e basicamente através de sucessivas decepções no trabalho, perdas acumuladas, exigências excessivas de desempenho, excesso de competitividade, inclusive com riscos de perdas de ocupações e empregos. (BRASIL; OPAS, 2001, p. 178).

Ademais, conforme destacado acima, verifica-se que, dentre as caracterizações de episódios depressivos encontram-se os atos suicidas. Com relação ao suicídio (inclusive a sua tentativa), pode-se compreender que o mesmo “[...] consiste em um processo complexo que se choca com um suposto instinto de sobrevivência" e que, mesmo diante uma possível variedade de conceitos e o seu tabu envolvido, trata-se de uma patologia, e que, quando relacionada ao trabalho, "[...] como ato extremo que é, cometido ou tentado por trabalhadores que estiveram em profundo sofrimento, determinado ou mediado pelo ambiente ocupacional”, e nesse sentido compreendendo também que "[n]em todos decidem ser criativos na repetição e na monotonia; nem todos toleram as agruras de um trabalho sem sentido; nem todos suportam o vazio das “convivências estratégicas" que se estabelecem no âmbito das organizações". (BARUKI, 2015, p. 94-95).

Constatando as patologias ocupacionais citadas em linhas gerais, compreendendo-as como realidade nas organizações de trabalho contemporâneas, especialmente considerando estas provenientes da inserção e desenvolvimento do modo de produção toyotismo, resta confrontar tais situações ao Direito vigente com vistas a verificar os problemas de efetividade de direitos de proteção à saúde mental do trabalhador. 


\section{DA INEFETIVA PROTEÇÃo À SAÚde MENTAL DO TRABALHADOR PELO ORDENAMENTO JURÍDICO}

Sendo ou não a pretensão do legislador brasileiro e do M.T.E. ao longo da construção histórica do sistema jurídico de segurança e medicina do trabalho, em concretude verifica-se que tal sistema muito se coincide em adequação regulatória à realidade fática dos modos de produção do taylorismo-fordismo, ou seja, um sistema jurídico mais adequado a uma realidade em que a atividade desempenhada pelos trabalhadores nas relações empregatícias era quase toda de execução física e gerenciada, distribuída coletivamente entre os trabalhadores por sequências, com atividades repetitivas, impessoal.

Porém, tal coincidência não se constata satisfatoriamente ao comparar o mesmo sistema jurídico com a atual realidade em que se tem a inserção do modo produção do toyotismo, isto é, um sistema que não apresenta muita adequação a uma realidade contemporânea, em que a atividade desempenhada pelos trabalhadores é gradativamente exigida o seu saber fazer, a sua polivalência, a sua individualidade e a espoliação subjetiva do obreiro, com maior evidência de riscos psicossociais. Com efeito, tem-se um hiato entre a realidade fático-social e a efetiva proteção jurídico-trabalhista sistematizada conforme a seguir.

Na Consolidação das Leis do Trabalho (CLT), o seu Capítulo V é dedicado a disciplinar sobre a segurança e medicina do trabalho (BRASIL, 1943, on-line). Atualmente tal capítulo encontra-se predominantemente em vigor na forma das redações dadas pela Lei $\mathrm{N}^{\circ} 6.514$, de 22 de dezembro de 1977, Lei $\mathrm{N}^{\mathrm{o}} 7.855$, de 24 de outubro de 1989, Lei $\mathrm{N}^{\mathrm{o}} 12.740$, de 8 de dezembro de 2012, Lei № 12.997, de 18 de junho de 2014 e Lei № 13.103, de 2 de março de 2015.

Sobre a matéria da segurança e medicina do trabalho, destacam-se, a seguir as normas que contemplam a atuação legislativa de proteção ao trabalhador no tocante a sua saúde e segurança, bem como as competências que foram atribuídas ao Ministério do Trabalho e Emprego (M.T.E.). Ademais, a CLT não exclui as competências devidamente gerais e específicas atribuídas a demais órgãos e entidades da Administração Pública voltadas à saúde e à segurança, bem como as decorrentes de negociações coletivas de trabalho, segundo dispõe o artigo 154 do referido diploma. (BRASIL, 1943, on-line).

Assim, o legislador atribuiu, ao órgão nacional competente, poderes normativos para estabelecer regras específicas para a fiel execução dos preceitos legais acerca da segurança e da 
medicina do trabalho, segundo dispõe o inciso I do artigo 155 da CLT (BRASIL, 1943, on- line). A competência para atualmente regulamentar especificamente sobre segurança e medicina do trabalho se dá por meio de um instrumento jurídico do M.T.E. denominado Norma Regulamentadora (NR), aprovada por meio de ato administrativo sob a espécie Portaria.

A execução de ações destinadas à saúde do trabalhador está incluída na atuação do Sistema Único de Saúde (SUS), bem como de rever periodicamente a lista de doenças relacionadas ao trabalho, nos termos da Lei $\mathrm{N}^{\circ}$ 8.080, de 19 de setembro de 1990, em seu artigo $6^{\circ}$, inciso I, alínea “c" e inciso VII do $§ 3^{\circ}$ do mesmo artigo. (BRASIL, 1990, on-line). A Lista de Doenças Relacionadas ao Trabalho foi instituída pela da Portaria $\mathrm{N}^{\mathbf{0}} 1.339$, de 18 de novembro de 1999, editada pelo Ministro da Saúde (BRASIL, 1999, on-line).

Às empresas, nos termos dos artigos 162 e 163 da CLT (BRASIL, 1943, on-line), há a obrigatoriedade de manter dois órgãos de segurança e de medicina do trabalho, sendo um deles os Serviços Especializados em Segurança e em Medicina do trabalho (SESMT) e o outro a Comissão Interna de Prevenção de Acidentes (CIPA), observadas as exigências normativas instituídas pelo M.T.E.

Além disso, os artigos 166 e 167 da CLT (BRASIL, 1943, on-line) obrigam as empresas a fornecer gratuitamente aos seus empregados o devido equipamento de proteção individual (EPI), porém, determina que esse equipamento seja "[...] adequado ao risco e em perfeito estado de conservação e funcionamento, sempre que as medidas de ordem geral não ofereçam completa proteção contra os riscos de acidentes e danos à saúde dos empregados”, e a utilização do mesmo somente poderá ocorrer se nele houver a devida "[...] indicação do Certificado de Aprovação do Ministério do Trabalho."

Já com relação às medidas preventivas de medicina do trabalho, a partir de suas redações dadas pela Lei $\mathrm{N}^{\circ} 7.855$, de 24 de outubro de 1989, houve uma exigência mais precisa que engloba a proteção à saúde mental do trabalhador através da submissão obrigatória deste, e por conta do empregador e de acordo com as regulamentações do M.T.E., aos exames médicos admissionais, demissionais e periódicos, pois, de acordo com o $\S 2^{\circ}$ do artigo 168 da CLT, na ocasião da realização desses exames, “[o]utros exames complementares poderão ser exigidos, a critério médico, para apuração da capacidade ou aptidão física e mental do empregado para a função que deva exercer.” (BRASIL, 1943, on-line) (grifo nosso).

Ao observar as disposições celetistas acerca "das edificações", "iluminação", "conforto térmico", "instalações elétricas", "movimentação, armazenagem e manuseio de materiais", "máquinas e equipamentos", "caldeiras, fornos e recipientes sob pressão", "atividades 
insalubres ou perigosas" e "prevenção da fadiga", respectivamente em seus artigos 170 a 199 da CLT (BRASIL, 1943, on-line), nota-se que elas comumente se tratam de questões voltadas ao meio ambiente do trabalho em seu aspecto predominantemente físico e não organizacional quanto aos modos de execução do trabalho nas relações interpessoais em que concentram os riscos psicossociais.

Ademais, em relação às atividades insalubres, elas são assim consideradas quando aprovadas pelo M.T.E. e que exponham o trabalhador a agentes nocivos à sua saúde em níveis intoleráveis segundo disposições técnicas a respeito, com base no que dispõe os artigos 189 e 190 da CLT. (BRASIL, 1943, on-line). Atualmente, as atividades insalubres são tecnicamente regulamentadas através da NR-15 a qual contém seus anexos disciplinando sobre os agentes físicos, químicos e biológicos (BRASIL, 2015a, on-line). Contudo, pelo que constam tanto na CLT quanto na NR-15, as definições de atividades insalubres limitam-se apenas aos fatores de risco físicos, químicos e biológicos.

Como se pode observar com as abordagens da sistemática jurídica supracitadas, verificase a construção de um complexo normativo focado para a saúde e a segurança do trabalhador contra ambientes noviços, mas com uma nocividade pautada apenas na segurança e saúde físicas do trabalhador e as poucas regulações inerentes à saúde mental estão relacionadas basicamente como consequências de exposições a agentes nocivos supracitados e não contemplando os riscos psicossociais inerentes às atuais organizações de trabalho.

Já em relação às atividades perigosas, embora para serem assim consideradas deva observar sua forma regulamentada pelo M.T.E. e sua sistemática também seja focada inicialmente à proteção física do trabalhador, com as redações dadas pela Lei $\mathrm{N}^{\circ} 12.740$, de 8 de dezembro de 2012, e também pela Lei № 12.997, de 18 de junho de 2014, ao instituírem a nova redação do artigo 193, seus incisos I e II e $\S 4^{\circ}$ da CLT (BRASIL, 1943, on-line), a contemplação da exposição permanente a "inflamáveis, explosivos ou energia elétrica", bem como a "[...] roubos ou outras espécies de violência física nas atividades profissionais de segurança pessoal ou patrimonial" e por fim ao considerar como atividade perigosa expressamente a de "[...] trabalhador em motocicleta", o legislador consequentemente acabou reforçando para a contribuição na configuração de um risco não somente físico, mas também psicossocial de certo modo em tais condições de trabalho, bastando, por exemplo, imaginar um empregado de uma empresa de transporte de valores em carro-forte, assim trabalhando, venha a sofrer um assalto por um grupo de criminosos fortemente armados e utilizando enorme violência, o que pode 
resultar a esse trabalhador a geração de um transtorno de estresse pós- traumático, (conforme explicado no item anterior do presente estudo), sendo, por sua vez, uma patologia ocupacional decorrente de riscos psicossociais no trabalho. Apesar desse efeito de inovação, tal mudança legislativa é insuficiente para atender as necessidades enfáticas nas diversas organizações de trabalho instituídas sob a inserção do modo de produção toyotismo.

Por fim, a CLT deu uma possibilidade de se instituir, por meio de atos administrativos normativos, regras capazes de disciplinar com maior efetividade a proteção à saúde mental do trabalhador contra doenças relacionadas ao trabalho oriundas de riscos psicossociais no trabalho. O artigo 200 da CLT atribuiu ao M.T.E. a competência normativa para dispor complementarmente sobre regras de segurança e medicina do trabalho "[...] tendo em vista as peculiaridades de cada atividade ou setor de trabalho [...]”. (BRASIL, 1943, on-line).

Entretanto, assim como o artigo 200 da CLT atribuiu ao M.T.E. a supramencionada essa competência normativa, pelo efeito de tal comando legal, também deu consequentes margens de discricionariedade para o seu exercício, tornando incerta a edição de instrumentos normativos efetivos para disciplinar a proteção à saúde mental do trabalhador contra os riscos de doenças oriundas a riscos psicossociais existentes no ambiente organizacional.

\section{DA PROTEÇÃo À SAÚdE MENTAL DO TRABALHADOR NA PERSPECTIVA DOS DIREITOS FUNDAMENTAIS}

\subsection{Disposições constitucionais sobre a proteção à saúde do trabalhador}

Tanto a dignidade da pessoa humana quanto o valor social do trabalho estão encartados na Constituição de 1988 como espécies de princípios fundamentais da República Federativa do Brasil, segundo previsto nos incisos III e IV do artigo $1^{\circ}$ do mesmo diploma magno (BRASIL, 1988, on-line). Sarlet (2001, p. 68-71) esclarece no sentido de que, quando o Poder Constituinte decidiu por incluir a dignidade da pessoa humana no rol dos princípios fundamentais contidos na redação do artigo $1^{\circ}$, não a tornou em si um direito fundamental e sim a atribuição de “condição de princípio (e valor) fundamental".

Classificando os princípios fundamentais supracitados segundo o grau de concretização dos mesmos, tratam-se, segundo Bulos (2015, p. 281), de "princípios estruturantes", isto é, que "[...] indicam as ideias norteadoras do Estado de Direito Democrático. Equivalem às linhas mestras da Constituição Federal [...]”. 
Por conseguinte, explica o referido autor que a concretização de tais princípios perfazse não somente por meio de princípios constitucionais gerais ou especiais, mas também por normas constitucionais, independentemente de qual seja a sua natureza, aplicabilidade ou eficácia, e a esse respeito, segundo o pós-positivismo, a norma é gênero, tendo como espécies as regras e os princípios, e estes por sua vez considerados como "supernormas" no sentido a sua posição central, autoaplicável, onivalente, e autorreferente nas constituições. (BULOS, 2015, p. 282). Nesse sentido, segue o entendimento de Alexy (2008, p. 90):

\begin{abstract}
Princípios são, por conseguinte, mandamentos de otimização, que são caracterizados por poderem ser satisfeitos em graus variados e pelo fato de que a medida de vida de sua satisfação não depende somente das possibilidades fáticas, mas também das possibilidades jurídicas. Já as regras são normas que são sempre ou satisfeitas ou não. Se uma regra vale, então, deve-se fazer exatamente aquilo que ela exige; nem mais, nem menos. Regras contêm, portanto, determinações do âmbito daquilo que é fática e juridicamente possível.
\end{abstract}

O princípio fundamental da dignidade da pessoa humana, ao ser assim instituído na Constituição de 1988, “[...] está consagrando um imperativo de justiça social [...]”. (BULOS, 2015, p. 284).

\begin{abstract}
A dignidade humana reflete [...] um conjunto de valores civilizatórios incorporados ao patrimônio do homem. Seu conteúdo jurídico interliga-se às liberdades públicas, em sentido amplo, abarcando aspectos individuais, coletivos, políticos e sociais do direito à vida, dos direitos pessoais tradicionais, dos direitos metaindividuais (difusos, coletivos e individuais homogêneos), dos direitos econômicos, dos direitos educacionais etc. (BULOS, 2015, p. 284).
\end{abstract}

O princípio fundamental do valor social do trabalho, ao instituí-lo na redação juntamente com a livre iniciativa, o Estado brasileiro se assenta nestes dois princípios fundamentais e garante uma ordem econômica sob o regime capitalista, e podendo intervir na economia quando houver imperativos de valorização social do trabalho humano.

[...] a Constituição aduziu que a ordem econômica se funda nesse primado,
valorizando o trabalho do homem em relação à economia de mercado, nitidamente
capitalista. Priorizou, pois, a intervenção do Estado na economia, para dar significação
aos valores sociais do trabalho. Estes, ao lado da iniciativa privada, constituem os
pilares do Estado brasileiro. (BULOS, 2015, p. 284-285).

Com essas afirmações, é possível compreender no sentido de que o reconhecimento do direito de proteção à saúde mental do trabalhador, em otimização e a partir dos princípios fundamentais da dignidade da pessoa humana e do valor social do trabalho, requer concretudes em normas constitucionais voltadas a tal especificidade. A própria Constituição de 1988 direciona para essa concretude ao estabelecer normas constitucionais de proteção à saúde ora incidentes ao trabalhador, inclusive como de direitos fundamentais. 
O trabalho e a saúde são comumente direitos fundamentais sob a espécie de direitos sociais, segundo dispõe o caput do artigo $6^{\circ}$ da Constituição de 1988 e, além disso, e especialmente ao meio ambiente do trabalho, o inciso XXII do artigo $7^{\circ}$ do mesmo diploma magno assegura ao trabalhador o direito à “[...] redução dos riscos inerentes ao trabalho, por meio de normas de saúde, higiene e segurança" (BRASIL, 1988, on-line).

O referido direito fundamental do trabalhador coincide com a norma constitucional prevista no artigo 196 ao dispor que o direito à saúde implica no dever do Estado em garanti-lo por meio de políticas sociais e econômicas destinadas a reduzir risco de doença e de outros agravos, e o a artigo 200, inciso II do mesmo diploma magno também atribui ao Sistema Único de Saúde, nos termos da lei, a execução de ações de saúde do trabalhador (BRASIL, 1988, online), mas é importante ressaltar as atribuições do M.T.E. sobre as suas competências relacionadas a atuações de proteção à saúde do trabalhador.

Os direitos fundamentais, de início, têm sua eficácia numa estreita relação entre o sujeito privado e o Poder Público, ou seja, uma eficácia vertical tendo como sujeito ativo o indivíduo particular exigindo do Poder Público (sujeito passivo) a efetiva observância de determinados direitos fundamentais envolvidos. Contudo, ocorre que "[...] as crises sociais e econômicas do século XX modificaram a posição do sujeito passivo dos direitos fundamentais [...]", ao passo que assim foi se verificando no sentido de que "[...] as normas constitucionais assecuratórias de liberdades públicas não surtiam apenas efeitos verticais, apresentando também eficácia horizontal.” (BULOS, 2015, p. 303). Logo, compreende-se por eficácia horizontal dos direitos fundamentais como aquela que incide sua aplicação normativa também nas relações jurídicas entre particulares.

Por conseguinte, em tais relações jurídicas entre particulares, da aplicação dos direitos fundamentais, destacam-se duas teorias, a saber, a da eficácia indireta (ou mediata) e a da eficácia direta (ou imediata). Pela teoria da eficácia indireta, a aplicação dos direitos fundamentais é de maneira reflexa, ou seja, dependente de uma correspondente legislação intermediária, mas o seu direito fundamental implica numa dimensão proibitiva (que proíbe o legislador em editar normas contrárias a esse direito fundamental) e positiva (que determina o legislador a editar tais normas ponderando a sua possível aplicabilidade nas relações entre particulares), ao passo que a teoria da eficácia direta, tais direitos fundamentais são aplicáveis às relações entre particulares independentemente de legislação intermediária. (LENZA, 2014, p. 1064-1065).

Com efeito, nas relações jurídicas empregatícias, as normas constitucionais que versam sobre a proteção à saúde do trabalhador, em suas eficácias, vinculam o empregador a observá- 
las nos casos concretos incidentes em seus ambientes de laborais, tais como na composição de organizações de trabalho que não afetem lesivamente a saúde mental de seus empregados. Ocorre que, pelo que consta no teor tanto do artigo $7^{\circ}$ inciso XXII, quanto no caput do artigo

196 cumulado com o artigo 200 inciso II da Constituição de 1988, verifica-se, numa primeira análise, a dependência de regulamentações infraconstitucionais para tonar efetivamente aplicável sua essência jurídico-fundamental de proteção à saúde do trabalhador e, portanto, o seu enquadramento à teoria da eficácia indireta.

Porém, deve-se interpretar tal essência jurídico-fundamental a partir da dignidade da pessoa humana como princípio fundamental, e dai, por se tratar de direito à saúde (embora especificamente no ambiente de trabalho), sua aplicação não ficará a mercê de boas políticas públicas tanto em sua eficácia vertical quanto também na sua eficácia horizontal. Assim, partindo da ideia de aplicação imediata de alguns direitos fundamentais nas relações entre particulares, cumulada com a de aplicação imediata do direito à saúde, ambos sedimentados nos princípios estruturantes da dignidade da pessoa humana e do valor social do trabalho, a aplicação do direito fundamental de proteção à saúde do trabalhador num ambiente e organização de trabalho é possível, ao menos em sua dimensão proibitiva, a saber, de proibir o empregador de estabelecer organizações de trabalho capazes de lesar a saúde mental do empregado.

De qualquer modo, citando algumas medidas infraconstitucionais capazes de, em se tratando de eficácia horizontal, conferir efetividade na aplicação do direito fundamental de proteção à saúde obreira nas relações entre empregador e empregado num determinado ambiente e organização de trabalho, e em especial à saúde mental do trabalhador, além das abordagens mencionadas no item 3 do presente estudo, destacam-se algumas disposições da Lei 8.080, de 19 de setembro de 1990, e a NR-17 do M.T.E., conforme a seguir.

É dever do Estado garantir a saúde formulando políticas econômicas e sociais visando reduzir os riscos de doenças e demais agravos, e tal dever não exclui o das empresas, segundo preceitua cumulativamente os $\S \S 1^{\circ}$ e $2^{\circ}$ do artigo $2^{\circ}$ da Lei 8.080/90 (BRASIL, 1990, on-line). Por conseguinte, o trabalho e o meio ambiente estão entre os determinantes e condicionantes da saúde, e a esta diz respeito também a garantia de condições de bem-estar físico, social e mental do indivíduo e da coletividade, conforme a atual redação do artigo $3^{\circ}$ e de seu parágrafo único do mesmo diploma legal (BRASIL 1990, on-line). Tais fundamentos levam ao entendimento de que o empregador tem o dever de, no seu âmbito corporativo, estabelecer políticas capazes zelar pela 
saúde mental dos seus empregados contra os riscos psicossociais existentes em seu ambiente e organização de trabalho.

Através do M.T.E., suas ações voltadas às finalidades supracitadas não são suficientes para atender a efetiva proteção. Uma tímida iniciativa encontra-se no contexto da NR-17, que trata sobre ergonomia, especialmente no que constam os seus itens 17.5 e seus subitens (que tratam das condições ambientais de trabalho) e o 17.6, principalmente com os seus subitens 17.6.1 e 17.6.2, que versam sobre a organização do trabalho, dispondo estes no sentido de que esta organização deva "[...] ser adequada às características psicofisiológicas [sic] dos trabalhadores e à natureza do trabalho a ser executado", devendo, no mínimo, levar em consideração os seguintes pontos: "normas de produção", "modo de operação", "exigência de tempo", "determinação do conteúdo do tempo", "ritmo de trabalho" e "conteúdo de tarefas". (BRASIL, 2015b, on-line).

Ao que se pode observar, tal norma regulamentadora encontra-se em níveis ínfimos de proteção, com disposições genéricas e com vagueza prejudicial a uma efetiva exigência aos empregadores em estabelecer efetivas condições organizacionais de trabalho capazes de zelar pela proteção à saúde mental de seus empregados.

[...] é fato que a NR-17 representou um avanço enorme para a época em que foi publicada. No entanto, é preciso buscar inspiração no histórico de lutas descrito para buscar dar maior concretude às medidas que devem ser observadas para que as características psicofisiológicas [sic] dos trabalhadores sejam de fato contempladas no planejamento da organização do trabalho, aqui entendida no sentido mais amplo possível. (BARUKI, 2015, p. 144).

De qualquer modo, pelas considerações acima, é possível compreender que, apesar de não haver uma satisfatória regulamentação intermediária capaz de dar efetividade na proteção à saúde mental dos empregados submetidos a ambientes e organizações de trabalho instituídas pelo empregador, é pela dimensão proibitiva dos direitos fundamentais que se vislumbra um caminho jurídico para a referida efetividade por meio de proibições ou condições para práticas lesivas à saúde mental obreira, desde que também reconheça cumulativamente a eficácia horizontal do mesmo direito.

\subsection{Os tratados internacionais de direitos humanos sobre saúde do trabalhador e sua eficácia jurídica}

Há entendimentos no sentido de que o rol dos direitos fundamentais encartados no Título II não seja taxativo e sim exemplificativo. Assim, Bulos (2015, p. 345) sustenta no sentido de se 
tratar de uma consagração do "princípio da não tipicidade constitucional" e o ingresso de normas materialmente constitucionais na ordem jurídica brasileira, o que, em se tratando de tratados ou convenções internacionais sobre direitos humanos, tais documentos passariam a ter status de norma constitucional, tendo como base a redação do $\S 2^{\circ}$ do artigo $5^{\circ}$ da Constituição de 1988 ao dispor que "[o]s direitos e garantias expressos nesta Constituição não excluem outros decorrentes do regime e dos princípios por ela adotados, ou dos tratados internacionais em que a República Federativa do Brasil seja parte." (BRASIL, 1988, on-line).

Contudo, a partir da Emenda Constitucional no 45 de 2004, acrescentou-se no artigo $5^{\circ}$ da Constituição de 1988 o $\S 3^{\circ}$ dispondo que "[o]s tratados e convenções internacionais sobre direitos humanos que forem aprovados, em cada Casa do Congresso Nacional, em dois turnos, por três quintos dos votos dos respectivos membros, serão equivalentes às emendas constitucionais.” (BRASIL, 1988, on-line).

Atualmente, o posicionamento predominante do Supremo Tribunal Federal é o no sentido de que os tratados e convenções internacionais sobre direitos humanos possuem caráter supralegal (acima das leis e abaixo da Constituição), mas se um tratado internacional dessa natureza for aprovado conforme o disposto do $\S 3^{\circ}$ do artigo $5^{\circ}$ da Constituição de 1988 , tal documento jurídico terá status de norma constitucional, conforme a tese do Ministro Gilmar Mendes acolhida por maioria no plenário a qual segue o trecho de seu voto:

[...] parece mais consistente a interpretação que atribui a característica de supralegalidade [sic] aos tratados e convenções de direitos humanos. Essa tese pugna pelo argumento de que os tratados sobre direitos humanos seriam infraconstitucionais, porém, diante de seu caráter especial em relação aos demais atos normativos internacionais, também seriam dotados de um atributo de supralegalidade [sic].

Em outros termos, os tratados sobre direitos humanos não poderiam afrontar a supremacia da Constituição, mas teriam lugar especial reservado no ordenamento jurídico. Equipará-los à legislação ordinária seria submeter o seu valor especial no contexto do sistema de proteção dos direitos da pessoa humana. (BRASIL, 2009, p. 727) (grifo do autor).

Dos os atos internacionais em vigor no país, para o presente estudo é conveniente destacar as Convenções $N^{\circ} 155$ e 161 da Organização Internacional do Trabalho (OIT) e o Pacto Internacional sobre Direitos Econômicos, Sociais e Culturais, adotado pela Assembleia Geral das Nações Unidas. Tais atos internacionais, com base nas explicações acima, podem compreender-se como normas supralegais, haja vista tratar-se de documentos que dispõem sobre direitos humanos. Com efeito, seu patamar de superioridade implica na derrogação de legislações ordinárias e administrativas normas contrárias aos ditames estabelecidos nesses atos internacionais em vigor. 
A Convenção $\mathrm{N}^{\circ} 161$ da OIT, aprovada pelo Decreto Legislativo $\mathrm{N}^{\circ}$ 86, de 14 de dezembro de 1989, em vigor no Brasil desde o dia 18 de maio de 1991 e promulgada pelo Decreto No 127, de 22 de maio de 1991, dispõe sobre os "Serviços de Saúde do Trabalho." (BRASIL, 1991, on-line). Trata-se de um serviço especializado de saúde e segurança ao trabalhador no ambiente de trabalho.

Dentre os princípios de uma política nacional proposta na referida Convenção, Serviços de Saúde no Trabalho, referem-se a funções "essencialmente preventivas" e de orientação ao empregador, trabalhadores e representantes na empresa, dentre outros temas, sobre um adequado ambiente de trabalho seguro e salubre física e mentalmente, nos termos de seu artigo 1. (BRASIL, 1991, on-line).

Conforme os riscos à saúde no trabalho peculiares de cada empresa, os serviços de saúde no trabalho devem assegurar algumas funções, dentre as quais a de identificação e avaliação dos riscos existentes, vigia dos fatores e práticas do trabalho capazes de prejudicar a saúde do trabalhador, assessoria na organização do trabalho e também na área da saúde, acompanhamento à saúde ocupacional e participação na análise de respectivas doenças dos trabalhadores. (BRASIL, 1991, on-line).

Já Convenção $\mathrm{N}^{\circ} 155$ da OIT, aprovada pelo Decreto Legislativo $\mathrm{N}^{\circ}$ 2, de 17 de março de 1992, em vigor no Brasil desde 18 de maio de 1993 e promulgada pelo Decreto $\mathrm{N}^{\circ} 1.254$, de 29 de setembro de 1994, dispõe sobre a "Segurança e Saúde dos Trabalhadores e o Meio Ambiente de Trabalho" (BRASIL, 1994, on-line).

Em suas definições, a Convenção $\mathrm{N}^{\mathrm{o}} 155$ da OIT contempla os elementos mentais na definição de saúde dada por este documento jurídico internacional, tendo em vista a redação prevista na alínea "e" de seu artigo 3 ao dispor que "[...] o termo "saúde", com relação ao trabalho, abrange não só a ausência de afecções ou de doenças, mas também os elementos físicos e mentais que afetam a saúde e estão diretamente relacionados com a segurança e a higiene no trabalho." (BRASIL, 1994, on-line).

Sobre a insuficiência de Normas Regulamentadoras capazes de efetivamente disciplinarem regras de proteção à saúde mental do trabalhador nos ambientes e organizações de trabalho, verifica-se uma inobservância do Poder Público, ao menos qualitativa, ao que determina a Convenção $\mathrm{N}^{\circ} 155$ da OIT, haja vista que o seu artigo 4 dispõe que o país, dentre outras exigências e observações, deverá “[...] reexaminar periodicamente uma política nacional coerente em matéria de segurança e saúde dos trabalhadores e o meio ambiente de trabalho", com o objetivo de prevenção de acidentes e de danos à saúde durante, consequentes e relacionados ao 
trabalho, bem como a possível e razoável redução das causas de riscos no meio ambiente laboral, e, ademais, institui o dever de dar efetividade às referidas determinações conforme seu artigo 8. (BRASIL, 1994, on-line).

O Pacto Internacional sobre Direitos Econômicos, Sociais e Culturais, adotado pela Assembleia Geral das Nações Unidas, aprovado pelo Decreto Legislativo № 226, de 12 de dezembro de 1991, encontra-se em vigor no Brasil desde o dia 24 de abril de 1992 e foi promulgado pelo Decreto No 591, de 6 de julho de 1992. (BRASIL, 1992, on-line). Dentre os seus direitos contemplados, destaca-se para o presente estudo, a disposição prevista no artigo 12, item 1 no sentido de que o país reconhece "[...] o direito de toda pessoa de desfrutar o mais elevado nível possível de saúde física e mental.” (BRASIL, 1992, on-line). Ao que se pode observar neste dispositivo, para a efetiva prestação do direito à saúde, tem por como efeito um "mandamento de otimização", ou seja, a caracterização de um "princípio", o qual "[...] sua satisfação não depende somente das possibilidades fáticas, mas também das possibilidades jurídicas”, segundo a preleção de Alexy (2008, p. 90).

Em se tratando de saúde do trabalhador, há estabelecido no sentido de que o país deverá adotar medidas com a finalidade de assegurar o pleno exercício do direito à saúde, que incluirão as que forem necessárias para garantir a “[...] melhoria de todos os aspectos de higiene do trabalho e do meio ambiente", e também a "[...] prevenção e o tratamento das doenças [...] profissionais [...], bem como a luta contra essas doenças", nos termos das alíneas "b" e "c" do item 2 do artigo 12 do referido pacto internacional. (BRASIL, 1992, on-line).

\subsection{Enfrentamentos hermenêuticos para concretização dos direitos fundamentais}

Sobre a hermenêutica constitucional no Direito Trabalhista, Delgado (2012, p. 232) afirma que " $[\mathrm{u}] \mathrm{m}$ dos grandes desafios do moderno Direito do Trabalho brasileiro é realizar mais plenamente no seu interior a dimensão constitucional construída em 1988." O referido autor explica que, dentre alguns obstáculos a respeito, há

[...] o ainda insistente e injustificável manejo, por parte da comunidade jurídica, inclusive judiciária, de ultrapassado critério de análise da eficácia jurídica das normas constitucionais (enquadrando-as como autoexecutáveis ou não autoexecutáveis); ou, alternativamente, o manejo impróprio do critério moderno, de modo a suprimir, na prática, qualquer mínima eficácia jurídica a normas tidas como de eficácia contida ou de eficácia limitada. (DELGADO, 2012, p. 232) (grifo do autor). 
Bonavides (2004, p. 93-97), ao tratar da temática acerca do "sistema constitucional", chama a atenção quanto ao sentido hermenêutico à Constituição, explicando a partir de então, que o constitucionalismo clássico (de ideologia liberal) a reduzia a um mero instrumento jurídico (normativista) “[...] tendo por finalidade precípua limitar ou enfrear o exercício do poder", ou seja, Direito Constitucional coincidindo com Constituição, a qual separava o Estado da sociedade, o que assim resultou numa sociedade despolitizada, sendo que, em contrapartida, para um sistema constitucional, englobam-se forças e formas políticas necessariamente presas numa Constituição, e, além disso, esta em realidade se constitui de algo mais complexo, abrangendo também uma diversidade de poderes sociais, econômicos, militares e culturais, razão pela qual se tem a necessidade de colocá-la num sistema constitucional, segundo o qual abrange todas as forças supracitadas, visualizando-a não somente no seu aspecto formal, mas também material.

Contudo, para a realidade contemporânea, passando pela fase do constitucionalismo com bases de Estado Social, o referido autor chama a atenção acerca de uma dificuldade de tornar a Constituição um instrumento que conciliasse seus postulados no aspecto jurídico e político.

Todo o problema constitucional ainda hoje procede, contudo, da ausência de uma fórmula que venha combinar ou conciliar essas duas dimensões da Constituição: a jurídica e a política. A verdade é que ora prepondera uma, ora outra. No constitucionalismo clássico e individualista preponderou a primeira; no constitucionalismo social e contemporâneo, a segunda. E quando uma delas ocupa todo o espaço da reflexão e da análise, os danos e as insuficiências de compreensão do fenômeno constitucional se fazem presentes. (BONAVIDES, 2004, p. 95) (grifo do autor).

Como proposta de pensamento crítico e revisor, a teoria material da Constituição também poderia resultar numa outra consequência lesiva, que seria a "uma visão puramente ideológica e política da Constituição", prejudicando a juridicidade da mesma e por sua vez os direitos fundamentais pautados em ordem e segurança. (BONAVIDES, 2004, p. 100).

Apesar dessa afirmação, ao comentar acerca de uma relação entre norma e realidade fática, referente à conquista da efetividade das normas constitucionais no Brasil nas discussões envolvidas na construção da Constituição de 1988, Barroso (2009, p. 218) afirma que as referidas normas “[...] contêm comandos, mandamentos, ordens, dotados de força jurídica, e não apenas moral. Logo, sua inobservância há de deflagrar um mecanismo próprio de coação, de cumprimento forçado, apto a garantir-lhes a imperatividade [...].”

Houve uma tendência nos estudos constitucionalistas no sentido de propor um sistema capaz de realizar uma justa interpretação da norma constitucional, inserindo, no lugar de um 
sistema "axiológico-dedutivo" formalista, um sistema "axiológico-teleológico", de metodologia pluralista, assim comportando distintas formas de apreciar a norma em seu conteúdo, um sistema constitucional que contém fundamentos valorativos e finalísticos, mas, todavia, notouse que esse novo sistema, por politizar a Constituição ao máximo, prejudicava a juridicidade e a eficácia de suas normas, dando lugar a um subjetivismo por parte dos intérpretes. (BONAVIDES, 2004, p. 135-137)

O referido autor relata acerca da falta de tradição do Direito Constitucional tanto em sua teoria quanto prática como um grande obstáculo para o processo de interpretação constitucional, diferentemente do que ocorre com o Direito Civil, o qual suas reflexões jurídicas vêm de um largo processo histórico de séculos, "[...] ficando assim toda a teoria jurídica da interpretação constitucional tributária da metodologia do Direito Civil” e, apesar de nas últimas décadas surgirem reações doutrinárias com esforços voltados à hermenêutica constitucional, afirma sobre a necessidade de o sistema constitucional empregar métodos hermenêuticos capazes de "[...] acompanhar as variações dinâmicas da Constituição, presos atentamente ao critério evolutivo, sempre de fundamental importância para a análise interpretativa.” (BONAVIDES, 2004, p. 139140).

Tais dificuldades hermenêuticas às normas constitucionais, segundo o referido autor, também dizem respeito à interpretação dos direitos fundamentais (BONAVIDES, 2004, p. 580). Apesar disso, na predominante égide uma "Nova Hermenêutica", explica no sentido de que o "constitucionalismo de renovação da segunda metade do século XX" oferece, dentre os seus resultados, “[...] a elaboração de duas novas teorias hermenêuticas: uma de interpretação da Constituição, mais ampla, e outra de interpretação dos direitos fundamentais, mais restrita, ambas, porém, originais e autônomas [...]”. (BONAVIDES, 2004, p. 583).

Com relação aos direitos fundamentais, chama a atenção afirmando que os mesmos “[...], em rigor, não se interpretam; concretizam-se.” (BONAVIDES, 2004, p. 592). Assim citando Hãberle, Bonavides (2004, p. 596-597) discorre no sentido de que a eficácia dos direitos fundamentais não depende da lei e sim esta que tem sua eficácia dependente daqueles direitos, construindo uma teoria dos direitos fundamentais baseada na sua "efetividade" e estabelecendo "premissas de intensa aplicação" desses direitos na correspondente sociedade.

A doutrina da efetividade, segundo Barroso (2009, p. 218), “[...] consolidou-se no Brasil como um mecanismo eficiente de enfrentamento da insinceridade normativa e de superação da 
supremacia política exercida fora e acima da Constituição". Nisso, aponta o significado de efetividade:

Efetividade, em suma, significa a realização do Direito, o desempenho concreto de sua função social. Ela representa a materialização, no mundo dos fatos, dos preceitos legais e simboliza a aproximação, tão íntima quanto possível, entre o dever-ser normativo e o ser da realidade social. (BARROSO, 2009, p. 220) (grifo do autor).

Além disso, o referido autor explica que a supracitada doutrina "[...] incorporou e difundiu, no âmbito do direito constitucional, um conceito tradicionalmente apropriado pelo direito civil, mas que, na verdade, integra a teoria geral do direito: o de direito subjetivo." (BARROSO, 2009, p. 221) (grifo do autor).

Assim, o referido autor explica Barroso (2009, p. 222) no sentido de que, em se tratando de norma constitucional de "direitos subjetivos constitucionais" (mesmo sendo de direitos sociais), ela é imediatamente exigível do Poder Público ou de quem, ainda que sujeito particular, seja o destinatário da referida norma, cuja efetividade normativa assim se deva, mesmo que por prestações negativas, podendo estas serem exigidas judicialmente.

\section{CONCLUSÃO}

Sob a atual estruturação produtiva baseada no toyotismo, o modo que estabelecem as organizações laborais faz com que o "trabalho" distorça seu sentido enquanto característica que distingue o ser humano dos demais animais. Por esse modo, o trabalho, atualmente, não é um incontroverso sinônimo de atividade que transforma transcendentalmente o trabalhador na sua condição de ser humano, e por sua vez também não se configura como um absoluto sinônimo de liberdade, pois por vezes, pelo contrário, é determinante para causar doenças e prejuízos diversos à vida dos seres humanos ora mais vulneráveis nas relações de trabalho.

Com o taylorismo-fordismo, o valor do trabalho não está primado na personalidade do trabalhador e sim no que ele executa, isto é, mais importante do que a inteligência empregada é o resultado do que foi produzido. Já com o toyotismo, pela execução do trabalho, intensifica-se a exploração da polivalência e espolia-se o "saber fazer" do trabalhador, exigindo gradativamente não somente a qualidade física, mas também a mental do mesmo ser humano, inclusive com tal situação lesiva intensificada, em decorrência do individualismo e de relações de constante concorrência intraoperária num ambiente de insegurança para a manutenção e afirmação em postos de trabalho, ora reduzidos quantitativa ou qualitativamente. 
Daí, contemporaneamente, tem-se um ambiente laboral com condições amplamente propensas ao estabelecimento de organizações de trabalho grandemente ensejadoras de riscos psicossociais laborais, com potenciais capacidades de gerar doenças relacionadas ao trabalho. Uma organização de trabalho primada pela polivalência que vem sendo exigida aos empregados, agregada aos perigos submetidos na execução do trabalho e a sua alta instabilidade, viabiliza a construção de um ambiente laboral com condições altamente estressantes, de intensas, variadas e repetitivas cargas de trabalho, de exposição do trabalhador a grandes perigos, de assédios morais, de grandes inseguranças na manutenção do emprego, decepções e sofrimentos relacionados ao trabalho, e de suas desvalorizações sociais. Com efeito, constitui-se um ambiente laboral com amplos riscos de ocasionar doenças ao trabalhador relacionadas ao trabalho, ora capazes de atingir, sobretudo, a sua saúde mental.

Riscos psicossociais são realidades fáticas nas atuais organizações de trabalho e satisfatoriamente divulgadas nos estudos científicos especializados nesse tema, razão pela qual a obsolescência normativa de segurança e proteção à saúde do trabalhador torna-se injustificável e de indevida omissão por parte do Poder Público regulador em face da parte mais vulnerável nas relações de trabalho que é a parte trabalhadora.

A vigente legislação de proteção à saúde do trabalhador era mais apropriada a uma realidade em que a atividade produtiva era estruturada predominantemente sob o taylorismofordismo. O trabalho executado como atividades mecanizadas, com métodos que pregam a rotinização, o gerenciamento sequenciado e desprovido de amplas e complexas habilidades intelectuais do trabalhador, exposição a perigos e nocivos agentes físicos, químicos e biológicos, compõe um ambiente laboral com riscos à segurança e à saúde física do trabalhador e, para tanto, houve uma construção normativa protetora que, de certo modo, respondeu às necessidades apresentadas historicamente.

Porém, com a inserção do toyotismo como modelo agregado a atividade produtiva reestruturada, o referido modelo jurídico encontra-se insatisfatório e desatualizado para a efetiva proteção à saúde do trabalhador contra riscos psicossociais no trabalho. Uma organização de trabalho que prima pela polivalência exigida aos trabalhadores, conforme explicado acima, acumulada com a intensa exigência de seu saber fazer, de sua individualidade e de espoliação subjetiva, desencadeia aos mesmos uma série de riscos à sua saúde, não somente no aspecto físico, mas, sobretudo, mental. Com efeito, a vigente legislação de proteção à saúde do 
trabalhador, por omissão, não dá uma resposta de efetiva proteção contra os riscos psicossociais existentes na atual realidade das organizações de trabalho.

De qualquer modo, o efeito que tal omissão do Poder Público, sobretudo do M.T.E. quanto a sua competência normativa de aprovar Normas Regulamentadoras, consiste em inviabilizar a efetiva proteção à saúde mental do trabalhador no seu aspecto técnico e sistematizado, de caráter sobretudo preventivo, deixando de inserir indispensáveis disposições específicas capazes de afirmar a correta proteção contra riscos psicossociais, isto é, a inviabilização de efetiva proteção por falta de instrumentos administrativamente positivados para a fiel execução de direitos. Contudo, tal omissão não atinge a eficácia negativa de normas definidoras de tais direitos, ou seja, não é capaz de prejudicar o efeito jurídico de proibir a instituição e manutenção de ambientes de trabalho, cuja sua organização sujeita o trabalhador a potenciais riscos à sua saúde ocupacional, principalmente mental. Logo, a ausência de regulamentação técnica e específica não significa a irrestrita liberdade do empregador em estabelecer organizações de trabalho lesivas à saúde mental do trabalhador.

Compreendendo a dignidade da pessoa humana e o valor social do trabalho como princípios fundamentais republicados que estruturam o Direito no país, o intérprete passa ser norteado, sobretudo, quanto à eficácia otimizada dos direitos fundamentais concernentes à proteção à saúde do trabalhador, inclusive mental. Porém, a concretização de tais direitos, enquanto houver a omissão de regulamentações infraconstitucionais devidas, assenta-se na eficácia horizontal de tais normas constitucionais definidoras de direitos e em dimensão proibitiva. O que depende de norma infraconstitucional regulamentadora é a instituição de disciplinas normativas específicas, as quais podem definir direitos específicos infraconstitucionais que dão maior efetividade aos comandos constitucionais.

Com isso, o empregador torna-se vinculado a respeitar direitos fundamentais de proteção à saúde do trabalhador, e assim implicando limites na instituição e manutenção de organizações de trabalho violadoras a tais comandos constitucionais, conforme o caso concreto. Ademais, tais limites não decorrem de uma estrita relação jurídica de trabalho e sim de deveres institucionais da saúde no país.

A concretização de direitos fundamentais na seara trabalhista requer enfrentamentos de construção hermenêutica especializada, inclusive quando se referir a direitos de proteção à saúde do trabalhador que, numa visão formal, dependem regulamentações infraconstitucionais, mas o que na realidade vem ocorrendo é a omissão do legislador ou da Administração Pública em face de uma realidade fática que vem ocorrendo nas organizações de trabalho sujeitas a 
condições laborais expressivamente lesivas, que são as existências e desenvolvidos dos riscos psicossociais.

Normas constitucionais que definem direitos, referindo-se às de proteção à saúde do trabalhador na qualidade de direitos fundamentais, são normas dotadas de imperatividade e não meras orientações políticas direcionadas ao legislador infraconstitucional. Assim, a doutrina da efetividade aponta caminhos para uma eficiente concretização desses direitos, pelo menos no que tange ao efeito de proibir empregadores de instituir e manter ambientes com organizações de trabalho lesivas à saúde do trabalhador, especialmente referindo-se à saúde mental.

\section{REFERÊNCIAS}

ALEXY, Robert. Teoria dos direitos fundamentais. 5. ed. São Paulo: Malheiros, 2008.

ALVES, Giovanni. Dimensões da reestruturação produtiva: ensaios de sociologia do trabalho. 2. ed. Londrina: Praxis; Bauru: Canal 6, 2007.

Trabalho, corpo e subjetividade: toyotismo e formas de precariedade no capitalismo global. Trabalho, Educação e Saúde, Rio de Janeiro, v. 3, n. 2, p. 409-428, 2005. Disponível em: 〈http://www.scielo.br/pdf/tes/v3n2/09.pdf>. Acesso em: 22 ago. 2015.

ANTUNES, Ricardo. A era da informatização e a época da informalização: riqueza e miséria do trabalho no Brasil. In: . (org.). Riqueza e miséria do trabalho no Brasil. São Paulo: Boitempo, 2006. P. 15-26.

A nova morfologia do trabalho e suas principais tendências: informalidade, infoproletariado, (i)materialidade e valor. In: Brasil II. 1. ed. São Paulo: Boitempo, 2013. p. 12-27.

ARANHA, Maria Lúcia de Arruda; MARTINS, Maria Helena Pires. Filosofando: introdução à filosofia. 2. ed. São Paulo: Moderna, 1993.

BARROSO, Luís Roberto. Curso de direito constitucional contemporâneo: os conceitos fundamentais e a construção do novo modelo. 1. ed. São Paulo: Saraiva, 2009.

BARUKI, Luciana Veloso. Riscos psicossociais e saúde mental do trabalhador: por um regime jurídico preventivo. São Paulo: LTr, 2015.

BONAVIDES, Paulo. Curso de direito constitucional. 15. ed. São Paulo: Malheiros, 2004.

BRASIL. Constituição (1988). Constituição da República Federativa do Brasil: versão atualizada até a Emenda n. 88/2015. Disponível em: <http://www.planalto.gov.br/ccivil_03/Constituicao/Constituicao.htm>. Acesso em: 19 ago. 2015. 
Decreto No 127, de 22 de Maio de 1991. Promulga a Convenção nº 161, da Organização Internacional do Trabalho - OIT, relativa aos Serviços de Saúde do Trabalho. Diário Oficial [da] República Federativa do Brasil: Poder Executivo, Brasília, DF, 23 de maio de 1991. p. 9780. Disponível em: <http://www.planalto.gov.br/ccivil_03/decreto/19901994/D0127.htm>. Acesso em: 21 ago. 2015.

Decreto No 591, de 6 de Julho de 1992. Atos Internacionais. Pacto Internacional sobre Direitos Econômicos, Sociais e Culturais. Promulgação. Diário Oficial [da] República Federativa do Brasil: Poder Executivo, Brasília, DF, 7 de julho de 1992. p. 8713. Disponível em: <http://www.planalto.gov.br/ccivil_03/decreto/1990-1994/D0591.htm>. Acesso em: 21 ago. 2015.

Decreto No 1.254, de 29 de Setembro de 1994. Promulga a Convenção número 155, da Organização Internacional do Trabalho, sobre Segurança e Saúde dos Trabalhadores e o Meio Ambiente de Trabalho, concluída em Genebra, em 22 de junho de 1981. Diário Oficial [da] República Federativa do Brasil: Poder Executivo, Brasília, DF, 30 de setembro de 1994. p. 14819. Disponível em: <http://www.planalto.gov.br/ccivil_03/decreto/1990-1994/D1254.htm>. Acesso em: 20 ago. 2015.

Decreto-Lei № 5.452, de 1 de maio de 1943. Aprova a Consolidação das Leis do Trabalho. Diário Oficial [dos] Estados Unidos do Brasil: Atos do Governo, Rio de Janeiro, 09 agosto de 1943. p. 11937. Disponível em: <http://www.planalto.gov.br/ccivil_03/DecretoLei/Del5452.htm>. Acesso em: 18 ago. 2015.

. Lei $N^{\circ}$ 8.080, de 19 de setembro de 1990. Dispõe sobre as condições para a promoção, proteção e recuperação da saúde, a organização e o funcionamento dos serviços correspondentes e dá outras providências. Diário Oficial [da] República Federativa do Brasil: Poder Executivo, Brasília, DF, 20 de setembro de 1990. p. 18055. Disponível em: <http://www.planalto.gov.br/ccivil_03/Leis/L8080.htm>. Acesso em: 19 ago. 2015.

Ministério da Saúde do Brasil. Portaria N 1339, de 18 de Novembro de 1999. 1999. Disponível em: <http://bvsms.saude.gov.br/bvs/saudelegis/gm/1999/prt1339_18_11_1999.html>. Acesso em: 17 ago. 2015.

; Organização Pan-Americana da Saúde no Brasil (OPAS). Doenças

relacionadas ao trabalho: manual de procedimentos para os serviços de saúde. Brasília, DF: Ministério da Saúde do Brasil, 2001. Disponível em:

<http://dtr2004.saude.gov.br/susdeaz/instrumento/arquivo/16_Doencas_Trabalho.pdf >. Acesso em: 17 ago. 2015.

Ministério do Trabalho e Emprego. Norma Regulamentadora $\mathbf{N}^{\mathbf{0}} 15$. Atividades e Operações Insalubres. Disponível em:

<http://portal.mte.gov.br/data/files/8A7C816A47594D040147D14EAE840951/NR15\%20(atualizada\%202014).pdf $>$. Acesso em 19 ago. 2015a.

. Norma Regulamentadora $\mathbf{N}^{\mathbf{0}}$ 17. Ergonomia. Disponível em:

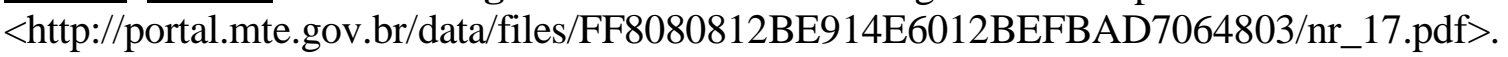
Acesso em 20 ago. 2015b. 
. Supremo Tribunal Federal. Recurso Extraordinário N 349.703-1. Banco Itaú S.A. e Armando Luiz Segabinazzi. Relator Ministro Carlos Britto. Relator para o Acórdão Ministro Gilmar Mendes. Diário da Justiça Eletrônico, Brasília, DF, n. 104, 4 de junho de 2009. Disponível em:

<http://redir.stf.jus.br/paginadorpub/paginador.jsp?docTP=AC\&docID=595406>. Acesso em: 21 ago. 2015.

BULOS, Uadi Lammêgo. Direito constitucional ao alcance de todos. 6. ed. São Paulo: Saraiva, 2015.

CASTEL, Robert. As metamorfoses da questão social: uma crônica do salário. Rio de Janeiro: Vozes, 1998.

DELGADO, Mauricio Godinho. Curso de direito do trabalho. 11. ed. São Paulo: LTr, 2012.

DUGUIT, Léon. Fundamentos do direito. 2. ed. São Paulo: Ícone, 2006.

FRANCO, Tânia. Karoshi: o trabalho entre a vida e a morte. Caderno CRH, Salvador, n. 37, p. 141-161, jul./dez. 2002. Disponível em: <http://www.flexibilizacao.ufba.br/RCRH-2006133tania.pdf>. Acesso em: 17 ago. 2015.

GIL, Antonio Carlos. Como elaborar projetos de pesquisa. 4. ed. São Paulo: Atlas, 2002.

LAFER, Celso. A reconstrução dos direitos humanos: um diálogo com o pensamento de Hannah Arendt. São Paulo: Saraiva, 1988.

LENZA, Pedro. Direito constitucional esquematizado. 18. ed. São Paulo: Saraiva, 2014.

MARCONI, Maria de Andrade; LAKATOS, Eva Maria. Fundamentos da metodologia científica. 5. ed. São Paulo: Atlas, 2003.

NAVARRO, Vera Lucia; PADILHA, Valquíria. Dilemas do trabalho no capitalismo contemporâneo. Psicologia \& Sociedade, Porto Alegre, v. 19, n. spe, p. 14-20, 2007.

Disponível em: <http://www.scielo.br/pdf/psoc/v19nspe/v19nspea04.pdf〉. Acesso em: 18 ago. 2015.

PINTO, Geraldo Augusto. Gestão global e flexível: trabalho local e adoecido. In: ANTUNES, Ricardo (org). Riqueza e miséria do trabalho no Brasil II. 1. ed. São Paulo: Boitempo, 2013. p. 165-181.

SARLET, Ingo Wolfgang. Dignidade da pessoa humana e direitos fundamentais na Constituição Federal de 1988. Porto Alegre: Livraria do Advogado, 2001. 